\title{
Tiltak for akutte smerter hos spedbarn
}

Resultatene fra en ny Cochraneoversikt viser at ulike tiltak for smertelindring hos spedbarn kan ha effekt. Spesielt kengurumetoden, smokkbruk og svøping/holding kan gi smertelindring.

Smertelindring er en metode eller teknikk som skal minke smertefølelsen eller smertetolkningen ved å unngå eller begrense eksponeringen til smerteutløsende stimuli. Hælprikking, venepunksjon og sprøytestikk kan typisk utløse smerte hos spedbarn. Mens bleieskift, intubering og veiing kan utløse smerte hos premature spedbarn. For å redusere eller forhindre smerte hos spedbarn benyttes ulike tiltak. Det kan dreie seg om forandring i omgivelsene, for eksempel lavt støynivå og belysning, slå sammen prosedyrer for å unngå overhåndtering av spedbarnet og beroligende lukter. Eller det kan være kognitive tiltak, for eksempel avledning ved bruk av leker eller video, eller mer atferdsrettete tiltak, for eksempel kengurumetoden, svøping/holding, vugging og smokkbruk.

\section{HVA SIER FORSKNINGEN?}

Forfatterne fant 51 studier som vurderte effekter av ikke-farmakologiske tiltak:

- Premature spedbarn: kengurumetoden, smokkbruk eller svøping/holding gir muligens mindre akutte smerter og ubehag

- Spedbarn opptil en måned gamle: smokkbruk eller vugging gir muligens mindre akutte smerter og ubehag

\section{HVA ER DENNE \\ INFORMAS JONEN BASERT PÅ?}

Forskerne i Cochrane-samarbeidet har laget en ny oversikt over randomiserte studier som har undersøkt effekten av ikkefarmakologiske tiltak på akutte smerter hos barn. Forskerne gjorde systematiske søk i flere databaser, og fant 51 randomiserte studier med til sammen 3396 barn som de inkluderte i oversikten. Studiene var gjennomført i USA, Canada, Frankrike, Brasil, Australia, Kina, Finland, Italia, Iran, Saudi-Arabia, Sør-Korea, Israel, Tyrkia og Taiwan. Tjuefem av studiene inkluderte premature spedbarn (født før 36. svangerskapsuke), 16 hadde barn født til termin (født fra uke 37 til en måned gamle). Elleve av studiene inkluderte spedbarn og småbarn (fra en måned til 36 måneder gamle).

\section{KILDE}

Pillai Riddell RR, Racine NM, Turcotte $K$, Uman LS, Horton RE, Din Osmun L, Ahola Kohut S, Hillgrove Stuart J, Stevens $B$, Gerwitz-Stern A. Non-pharmacological management of infant and young child procedural pain. Cochrane Database of Systematic Reviews 2011, Issue 10. Art. No.: CD006275. DOI: 10.1002/14651858.CD006275.pub2.

Skrevet av Marita Sporstøl Fønhus, Nasjonalt kunnskapssenter for helsetjenesten 


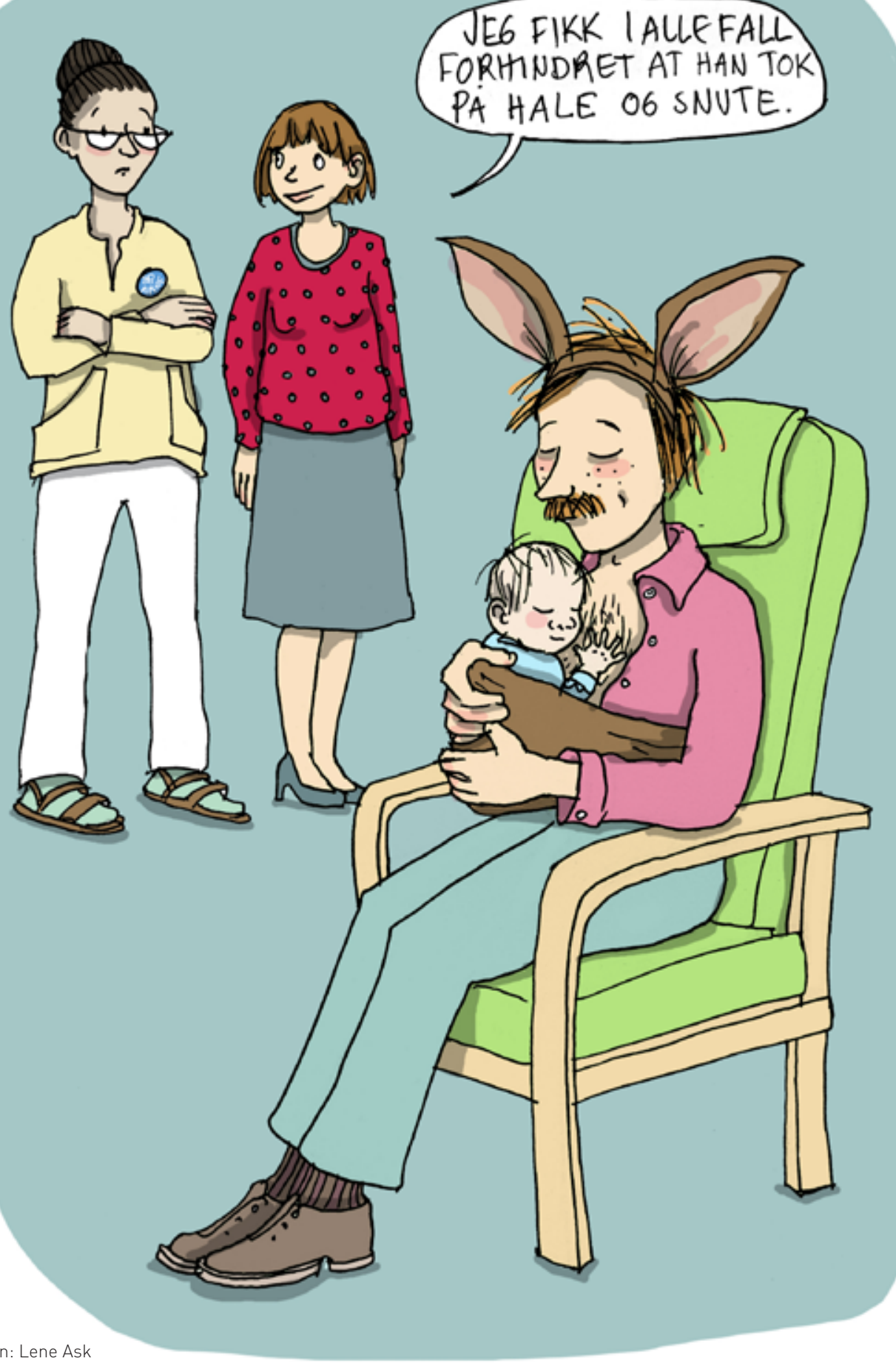

